\title{
PENGEMBANGAN MEDIA PEMBELAJARAN ULAR TANGGA KIMIA (ULTAKIM) BERBASIS KEMARITIMAN PADA MATERI HAKIKAT ILMU KIMIA
}

\section{THE DEVELOPMENT OF MARITIME BASED CHEMICAL SNAKE LADDER (ULTAKIM) LEARNING MEDIA IN THE NATURE OF CHEMISTRY TOPIC}

\author{
Dina Karina*, Inelda Yulita, Eka Putra Ramdhani \\ Program Studi Pendidikan Kimia, Universitas Maritim Raja Ali Haji \\ Jl.Politeknik Senggarang, Tanjungpinang, Kepulauan Riau 29125 \\ *e-mail korespondensi: dinakarina.96@gmail.com
}

\begin{abstract}
Abstrak
Kurangnya media pembelajaran merupakan salah satu masalah yang terdapat di SMAN 1 Singkep Barat. Pembelajaran yang monoton membuat siswa kurang tertarik dan merasa bosan pada saat proses pembelajaran. Tujuan dari penelitian ini adalah untuk : 1) mengembangkan media pembelajaran ULTAKIM berbasis kemaritiman; 2) mengetahui validitas media pembelajaran ULTAKIM; 3) mengetahui tanggapan siswa terhadap media pembelajaran ULTAKIM berbasis kemaritiman yang dikembangkan. Jenis penelitian ini adalah penelitian pengembangan (R\&D) yang dikembangkan melalui tahapan 1) define, 2) design, dan 3) development. Instrumen pengumpulan data yang digunakan adalah lembar observasi, lembar validasi, dan lembar respon siswa. Hasil penelitian yang diperoleh yaitu rata-rata persentase validasi oleh ahli media sebesar $97,5 \%$ dengan kriteria sangat layak, ahli materi diperoleh persentase sebesar $93,7 \%$ dengan kriteria sangat layak. Berdasarkan penilaian tersebut, maka media pembelajaran ULTAKIM berbasis kemaritiman pada materi hakikat ilmu kimia yang telat dikembangkan layak digunakan dalam kegiatan pembelajaran kimia.
\end{abstract}

Kata kunci: media pembelajaran, media ular tangga kimia, kemaritiman

\begin{abstract}
The lack of learning media is one of the problems found in SMAN 1 Singkep Barat. Monotonous learning makes students less interested and bored during the learning process. The objectives of this study are to: 1) develop maritime-based ULTAKIM learning media; 2) knowing the validity of ULTAKIM learning media; 3) knowing the students' responses to the developed maritime-based ULTAKIM learning media. This type of research is development research (R \& D) which was developed through stages 1) define, 2) design, and 3) development. The data collection instruments used were observation sheets, validation sheets, and student response sheets. The results of the research obtained were the average percentage of validation by media experts at $97.5 \%$ with very decent criteria, material experts obtained a percentage of $93.7 \%$ with very feasible criteria. Based on these assessments, the maritime-based ULTAKIM learning media in the material of the nature of chemistry that is late developed is appropriate for use in chemical learning activities.
\end{abstract}

Keywords: learning media, snake ladder chemical media, maritime 


\section{PENDAHULUAN}

Pendidikan menjadi perhatian serius bangsa Indonesia mengingat pentingnya peranan pendidikan dalam kemajuan bangsa (Pramita \& Agustini, 2016). Permasalahan yang ada pada pendidikan perlu mendapat perhatian yang serius dari pemerintah. Salah satu masalah yang dihadapi dunia pendidikan kita adalah masalah lemahnya proses pembelajaran (Agung, 2012). Dalam proses pembelajaran, siswa kurang didorong untuk mengembangkan kemampuan berpikir karena proses pembelajaran di dalam kelas diarahkan kepada kemampuan siswa untuk menghafal informasi (Pratiwi dkk, 2015). Tujuan mengatasi masalah dalam pendidikan adalah untuk meningkatkan kualitas pendidikan yang mencakup berbagai bidang seperti kualitas kurikulum, prasarana, proses belajar mengajar, peningkatan kualitas guru, dan usaha-usaha lain yang tercakup dalam komponen pendidikan.

Guru merupakan faktor penting dalam menentukan keberhasilan pembelajaran. Guru tidak hanya dituntut untuk memiliki kemampuan dalam pengalaman teoritis tapi juga harus memiliki kemampuan praktis. Kedua hal ini sangat penting karena seorang guru dalam pembelajaran bukan hanya sekedar menyampaikan materi tetapi juga harus mampu mendesain pembelajaran menjadi menyenangkan dan mudah dipahami bagi siswa (Rosyana dkk, 2014).

Berdasarkan hasil wawancara dengan guru mata pelajaran kimia, salah satu media yang digunakan guru adalah media powerpoint, namun tidak berpengaruh signifikan terhadap ketertarikan siswa dalam belajar. Media powerpoint yang digunakan oleh guru hanya berisi tulisan tanpa adanya animasi atau gambar, sehingga murid menjadi bosan. Hal ini mengakibatkan siswa menjadi kurang aktif pada saat proses pembelajaran, sehingga ketidaktertarikan siswa dengan model pembelajaran dan media pembelajaran yang diberikan guru mempengaruhi hasil belajar siswa. Berdasarkan observasi yang dilakukan di salah satu SMA Negeri tentang analisis kebutuhan peserta didik dengan menggunakan angket, diperoleh keterangan bahwa peserta didik lebih menyukai suasana pembelajaran yang menyenangkan dan tidak monoton, bukan pembelajaran yang hanya menghafal dan peserta didik membutuhkan media pembelajaran seperti permainan.
Salah satu cara mengatasi masalah tersebut adalah dengan pemanfaatan media pembelajaran lainnya selain media powerpoint. Penggunaan media pembelajaran secara signifikan mampu meningkatkan pencapaian hasil belajar (Asyhar, 2012). Dengan menggunakan media pembelajaran yang tepat dan kreatif dapat menjadikan pembelajaran tidak monoton dan membosankan. Dengan demikian, siswa akan lebih mudah tertarik dan memahami pelajaran.

Salah satu media visual yang dapat menjadi solusi permasalahan siswa dalam pembelajaran adalah media pembelajaran Ular tangga Kimia (ULTAKIM) berbasis kemaritiman. Media pembelajaran ULTAKIM merupakan inovasi perpaduan antara media ular tangga dan monopoli. Papan ULTAKIM, aturan permainan dan kartu soal didesain dengan tema kemaritiman. Pada media ULTAKIM terdapat papan ular tangga, bidak pemain, dadu dan kartu soal. Selain itu terdapat dua jenis kartu soal merah dan hijau. Kartu soal merah terdapat pada ekor ular dan kartu soal hijau terdapat pada kotak yang berisi tangga.

Keunggulan media ULTAKIM yang dikembangkan peneliti ialah berbasis kemaritiman, media ULTAKIM mempunyai perbedaan dengan media yang sudah ada dari segi materi, desain papan ULTAKIM, aturan permainan dan kartu soal yang bertemakan kemaritiman.

\section{METODE PENELITIAN}

Jenis penelitian yang digunakan dalam penelitian ini yaitu penelitian dan pengembangan (Research and Development) /R\&D. Adapun Penelitian ini berfokus pada validasi dari ahli media dan ahli materi terhadap pengembangan media pembelajaran Ular Tangga Kimia (ULTAKIM) berbasis kemaritiman pada materi hakikat ilmu kimia. Pengumpulan data penelitian ini dilakukan dengan cara memberikan angket. Angket ini berisikan pernyataan yang disertai dengan pilihan jawaban yang digunakan untuk memperoleh informasi dari subjek yang akan diteliti. Lembar angket disusun sedemikian rupa sehingga responden dapat memberikan penilaian langsung pada angket tersebut. Adapun angket tersebut terdiri dari angket validasi media dan angket validasi materi. Data angket dimaksudkan untuk mengetahui validasi media ULTAKIM. 
Data hasil penelitian yang diperoleh dari uji validitas oleh ahli diolah dengan menggunakan analisis secara deskriptif dengan memperhatikan aspek-aspek terkait perancangan media pembelajaran ULTAKIM berbasis kemaritiman yang ditinjau dari bentuk media, visual, dan penyajian konsep. Media pembelajaran ULTAKIM berbasis kemaritiman tidak hanya dinilai dari medianya saja tapi juga dari bahasa dan materinya. Kriteria penilaian terhadap validitas media pembelajaran ULTAKIM berbasis kemaritiman ini dinyatakan dalam persentase yang dihitung dengan menggunakan rumus:

$\%$ validitas $=\frac{\text { Skor rerata keseluruhan }}{\text { Skor fertinggi ideal keseluruhan }} \times 100 \%$

Validitas produk ditentukan dengan menghitung rata-rata dari validator, kemudian dicocokkan dengan tabel kriteria validitas produk pengembangan berikut:

Tabel 1. Kriteria Validitas Produk

\begin{tabular}{cccc}
\hline Skor & Rumus & Nilai & Klasifikasi \\
\hline 4 & $81 \%-100 \%$ & A & Sangat Layak \\
3 & $71 \%-80 \%$ & B & Layak \\
2 & $40 \%-60 \%$ & C & Kurang Layak \\
1 & $0 \%-39 \%$ & D & $\begin{array}{c}\text { Sangat Tidak } \\
\text { Layak }\end{array}$ \\
\hline
\end{tabular}

(Sumber: Modifikasi Arikunto, 2010)

\section{HASIL DAN PEMBAHASAN}

Validasi media pembelajaran ULTAKIM berbasis kemaritiman dilakukan oleh dua orang validator. Validasi ahli media yang dinilai ialah aspek isi dan penyajian, bahasa dan kegrafisan. Skor rata-rata validasi aspek isi dan penyajian adalah 96,2\% sesuai kriteria kelayakan perangkat pembelajaran pada Tabel 1, maka kriteria kelayakan analisis termasuk kategori sangat layak. Aspek kelayakan bahasa memiliki skor rata-rata validasi adalah $100 \%$ sesuai kriteria kelayakan perangkat pembelajaran pada Tabel 1, maka kriteria kelayakan analisis termasuk kategori sangat layak. Aspek kelayakan kegrafisan memiliki skor rata-rata validasi adalah $100 \%$ sesuai kriteria kelayakan perangkat pembelajaran pada Tabel 1, maka kriteria kelayakan analisis termasuk kategori sangat layak. Sehingga analisis secara keseluruhan memiliki skor $97,5 \%$ termasuk dalam kategori sangat layak. Analisis perhitungan bisa dilihat pada Tabel 2 .
Tabel 2. Hasil validasi Ahli Media

\begin{tabular}{ccc}
\hline No & Aspek Penilaian & $\begin{array}{c}\text { Persentase }(\%) \\
\text { Validasi 3 }\end{array}$ \\
\hline 1 & Isi dan Penyajian & 96,2 \\
2 & Bahasa & 100 \\
3 & Kegrafisan & 100 \\
\hline Total skor keseluruhan & 296,2 \\
Rata-rata & 97,5 \\
Kriteria & Sangat layak \\
\hline
\end{tabular}

Selanjutnya, validasi ahli materi yang dinilai ialah aspek materi pembelajaran, interaksi dan penggunaan bahasa tulis. Skor rata-rata validasi aspek materi pembelajaran $100 \%$ sesuai kriteria kelayakan perangkat pembelajaran pada Tabel 1, maka kriteria kelayakan analisis termasuk kategori sangat layak. Aspek kelayakan interaksi memiliki skor rata-rata validasi adalah $100 \%$ sesuai kriteria kelayakan perangkat pembelajaran pada Tabel 1, maka kriteria kelayakan analisis termasuk kategori sangat layak. Aspek kelayakan penggunaan bahasa tulis memiliki skor rata-rata validasi adalah $87,5 \%$ sesuai kriteria kelayakan perangkat pembelajaran pada Tabel 1, maka kriteria kelayakan analisis termasuk kategori sangat layak. Sehingga analisis secara keseluruhan memiliki skor $93,7 \%$ termasuk dalam kategori sangat layak. Analisis perhitungan bisa dilihat pada Tabel 3.

Tabel 3. Hasil validasi Ahli Materi

\begin{tabular}{ccc}
\hline No & Aspek Penilaian & $\begin{array}{c}\text { Persentase }(\%) \\
\text { Validasi 2 }\end{array}$ \\
\hline 1 & Materi Pembelajaran & 100 \\
2 & Interaksi & 100 \\
3 & Penggunaan Bahasa Tulis & 87,5 \\
\hline Total skor keseluruhan & 287,5 \\
Rata-rata & 93,7 \\
Kriteria & Sangat layak \\
\hline
\end{tabular}

\section{KESIMPULAN}

Berdasarkan hasil dari penelitian yang telah dilakukan dapat disimpulkan media pembelajaran ULTAKIM berbasis kemaritiman yang dikembangkan sangat layak dengan persentase penilaian kelayakan oleh validator ahli media diperoleh presentase sebesar $97,5 \%$ dan validator ahli materi diperoleh presentase sebesar 93,7\% maka, media pembelajaran ULTAKIM berbasis kemaritiman ini masuk dalam kategori sangat layak. 


\section{DAFTAR RUJUKAN}

Agung, I. (2012). Panduan Penelitian Tindakan Kelas bagi Guru. Jakarta: Bestari Buana Murni.

Arikunto, S. (2010). Prosedur Penelitian Suatu Pendekatan Praktik. Jakarta: Rineka Cipta.

Asyhar, R. (2012). Kreatif Mengembangkan Media Pembelajaran. Jakarta: Referensi Jakarta.

Pramita, A., Agustini, R. (2016). Pengembangan Media Permainan Ular Tangga pada Materi Senyawa Hidrokarbon Kelas XI SMA untuk Meningkatkan Pemahaman Konsep Siswa. Unesa Journal of Chemical Education, 5(2), 169-177.
Pratiwi, D. M., Saputro, S., \& Saputro, A.N.C. (2015). Pengembangan Lks Berbasis Inkuiri Terbimbing Pada Pokok Bahasan Larutan Penyangga Kelas Xi Ipa. Jurnal Pendidikan Kimia, 4(2), 32-37.

Rosyana, W., Mulyani, S., \& Saputro, S. (2014). Pembelajaran Model TGT (Teams Games Tournament) Menggunakan Media Permainan Monopoli dan Permainan Ular Tangga pada Materi Pokok Sistem Koloid Ditinjau dari Kemampuan Memori Kelas XI SMA Negeri Sragen Tahun Pelajaran 2012/2013. Jurnal Pendidikan Kimia, 3(4), 74-81. 